\title{
KRAKÓW JAKO STOLICA GENERALNEGO GUBERNATORSTWA. WPŁYW STOŁECZNOŚCI NA ŻYCIE MIASTA
}

Streszczenie. Celem artykułu pozostaje próba ukazania sytuacji Krakowa w okresie okupacji hitlerowskiej, kiedy miasto pełniło funkcję stolicy Generalnego Gubernatorstwa. Funkcja ta warunkowała wystąpienie szeregu nietypowych zjawisk. Z jednej strony miasto działało w zwykłym reżimie okupacyjnym, z drugiej zaś - stanowiło siedzibę władz, co skutkowało osiedleniem się w Krakowie tysięcy niemieckich funkcjonariuszy wraz z rodzinami. Miało to istotny wpływ na wiele wymiarów funkcjonowania Krakowa, począwszy od kwestii społecznych, mieszkaniowych, poprzez architekturę, gospodarkę, sposób przeprowadzenia eksterminacji ludności żydowskiej, na działalności polskiego podziemia kończąc. Osobną omawianą w artykule sprawą pozostaje nazistowska akcja propagandowa, której centrum stanowił Kraków. Ze względu na ograniczenia co do objętości artykułu wszystkie te zagadnienia zarysowane są w sposób syntetyczny, niemniej dający obraz specyfiki oraz odmienności wojennego doświadczenia Krakowa. Autor ukazuje, że losy miasta wymykają się utartym schematom oceny niemieckiej okupacji ziem II Rzeczypospolitej. W przeciwieństwie do wielu innych ośrodków Kraków nie był tylko miastem podbitym i kontrolowanym, ale pod wieloma względami stanowił zalążek nowego, kolonialnego, niemieckiego ładu w Europie Wschodniej.

Słowa kluczowe: Kraków, druga wojna światowa, Generalne Gubernatorstwo, okupacja niemiecka, Hans Frank

W czasie drugiej wojny światowej Kraków odgrywał rolę wyjątkową - był stolicą Generalnego Gubernatorstwa. Chociaż w różnych okresach historycznych mieszkańcy miasta z dumą podkreślali fakt jego stołeczności, to o funkcji podwawelskiego grodu w czasie niemieckiej okupacji niewiele i niechętnie się pamięta. Fakt ten traktowany jest jako rzeczywistość sztuczna, narzucona, która w żaden sposób nie oddziałała na proces kształtowania się tożsamości 
miasta. Poniekąd jest to słuszne podejście, trzeba jednak zdać sobie sprawę, że umiejscowienie stolicy Generalnego Gubernatorstwa pod Wawelem w bardzo istotny sposób wpłynęło na życie mieszkańców oraz funkcjonowanie całego organizmu miejskiego.

Warto już na wstępie nadmienić, że dzieje Krakowa w okresie drugiej wojny światowej stanowią bardzo szeroki temat, a literatura przedmiotu jest tutaj nad wyraz bogata ${ }^{1}$. Niniejszy krótki artykuł dotyka niektórych tylko zagadnień, wybranych pod kątem zasygnalizowanego w tytule problemu. W istocie tekst ten podsumowuje analizę zawartą w dotychczasowych pracach i uzupełnia ją o elementy nowej kwerendy archiwalnej.

W pierwszej kolejności przypomnijmy, dlaczego Niemcy podjęli decyzję o umiejscowieniu stolicy właśnie pod Wawelem. Od początku nie budziło raczej wątpliwości, że centralny ośrodek Generalnego Gubernatorstwa nie powinien znajdować się w Warszawie. Warto pamiętać, że pierwotnie rozpatrywano też kandydaturę Łodzi. Sytuację zmieniła jednak decyzja o bezpośrednim przyłączeniu tego miasta do III Rzeszy. W tej sytuacji naturalnym kandydatem stał się Kraków, tym bardziej że zaczęto dostrzegać jego liczne, przede wszystkim propagandowe, walory. Podwawelski gród uchodził w oczach nazistów za miasto eleganckie i europejskie, doskonale ilustrujące ideę rzekomej odwiecznej „niemieckości” ziem położonych nad Wisłą. Wspaniałe gotyckie budowle przywodziły na myśl Norymbergę, a renesansowa architektura świadczyła o poziomie kultury, który w żadnym wypadku nie mógł być możliwy do osiągnięcia wyłącznie przez słowiańskich „podludzi”2. Niezależnie od uwarunkowań o charakterze ideologicznym (o których będzie jeszcze mowa) nie bez znaczenia pozostawały też względy praktyczne - stosunkowa duża liczba nowoczesnych, niezniszczonych i dobrze wyposażonych gmachów użyteczności publicznej ${ }^{3}$.

Pierwszym, bezpośrednim rezultatem decyzji o umiejscowieniu stolicy Generalnego Gubernatorstwa pod Wawelem był napływ do miasta ogromnej liczby osób narodowości niemieckiej - nie tylko wojskowych, ale przede wszystkim

1 Vide: M. BednareK, K. Zimmerer, Okupanci. Niemcy w Krakowie 1939-1945, Kraków 2017; J. CHROBACZYŃSKI, Wojna a spoteczeństwo. Ze studiów nad spotecznością okupowanego Krakowa 19391945, Kraków 1989; A. Chwalba, Okupacyjny Kraków w latach 1939-1945, Kraków 2002; A. CzoCHER, W okupowanym Krakowie. Codziennośćpolskich mieszkańców miasta 1939-1945, Gdańsk 2011.

2 D. SCHENK, Krakauer Burg. Wawel jako ośrodek wtadzy Hansa Franka w latach 1939-1945, Kraków 2013, s. 80.

3 Ibidem, s. 78; A. ChWALBA, op. cit., s. 41-42. 
cywili. Podejmowali oni pracę na wszystkich szczeblach administracji państwowej oraz miejskiej, ale też w niemieckich instytucjach, których siedziby zlokalizowane zostały w stolicy Generalnego Gubernatorstwa. Pośród nich szczególną rolę odgrywały Niemieckie Koleje Wschodnie oraz Niemiecka Poczta Wschodnia . Idę̨ rzekomej odwiecznej niemieckości Krakowa aktywnie propagował powstały w miejsce Uniwersytetu Jagiellońskiego Instytut Niemieckiej Pracy Wschodniej5 Niezależnie od tego pod Wawelem instalowały się też firmy (np. budowlane), filie banków oraz sklepy - przy czym wszystkie zatrudniały niemieckich pracowników (przynajmniej na stanowiskach kierowniczych). Niejednokrotnie przybywali oni do Krakowa z całymi rodzinami. Wielkość niemieckiej populacji miasta szacuje się różnie. Największą liczebność osiągnęła ona prawdopodobnie późną wiosną 1944 r. (ok. 30 tys. ludzi). Poza tym według danych z przełomu roku 1943 i 1944 w mieście stacjonowało ok. 4 tys. niemieckich policjantów oraz 6-8 tys. żołnierzy rozmaitych formacji ${ }^{6}$. Jakkolwiek przesadzone wydają się w tym kontekście pojawiające się w literaturze przedmiotu stwierdzenia, jakoby co 4-5 mieszkaniec Krakowa był w tym czasie Niemcem, to z całą pewnością byli oni w mieście bardzo widoczni - szczególnie w centrum? ${ }^{7}$.

Przybywających do Krakowa Reichsdeutschów formalnie obowiązywała reguła izolowania się od miejscowej ludności. Faktycznie w wielu aspektach nie była ona przestrzegana, niemniej w istotny sposób wpływała na masowe powstawanie różnego rodzaju niemieckich instytucji, w tym szpitali, przychodni, osobnych sklepów. Dzieci osób przybywających z Rzeszy (a także Volksdeutschów) uczyły się w niemieckich szkołach ${ }^{8}$. O otwarciu pierwszej tego rodzaju placówki główny niemieckojęzyczny organ prasowy „Krakauer Zeitung” informował już

4 D. SCHENK, op. cit., s. 101-105.

5 Instytut Niemieckiej Pracy na Wschodzie (Institut für Deutsche Ostarbeit), powołany do życia 19 IV 1940 r., był to pseudonaukowy ośrodek, którego celem pozostawało prowadzenie badań nad niemieckim dziedzictwem Krakowa oraz Polski, bo to ono stanowiło jakoby główny, jeśli nie jedyny, impuls dla rozwoju cywilizacyjnego ziem położonych nad Wisłą. Instytut zatrudniał 195 pracowników, w tym 70 Niemców, vide: A. CHWALBA, op. cit., s. 48-49.

6 A. Czocher, op. cit., s. 7-8; A. ChWalba, op. cit., s. 36-37.

7 J. ChrobaczyŃski, Kraków - „stolica” Generalgouvernement (1939-1945), [w:] Kraków. Studia z dziejów miasta. W750 rocznicę lokacji, red. J. RaJMAN, Kraków 2007, s. 244.

8 Obowiązek rozdzielenia szkolnictwa według narodowości sankcjonowało rozporządzenie Hansa Franka z 31 X 1939 r., vide: IDEM, Nauczyciele w okupowanym Krakowie 1939-1945, Kraków 1989, s. 30 . 
17 stycznia 1940 r. ${ }^{9}$ W 1944 r. w Krakowie istniało już 11 szkół ludowych, do których uczęszczało około 2 tys. uczniów. Funkcjonowały też szkoły zawodowe oraz niemieckie gimnazjum ${ }^{10}$. Oprócz placówek oświatowych dzieci oraz młodzież zrzeszone były w nazistowskich organizacjach, wśród których prym wiodły Hitlerjugend oraz Bund Deutscher Mädel (Związek Dziewcząt Niemieckich) ${ }^{11}$. Okupanci posiadali także wyłączne prawo korzystania z niektórych lokali gastronomicznych, zwłaszcza tych najbardziej ekskluzywnych (takich jak np. Hawełka, Feniks oraz Wentzl). W 1942 r. było to już 14 restauracji, 6 kawiarni oraz 1 lokal dla policji1 ${ }^{12}$.

Obecność tak wielu Niemców w Krakowie robiła na Polakach przygnębiające wrażenie, tym bardziej że gwałtownej germanizacji poddano całą przestrzeń miasta. Począwszy od października 1940 r., rozpoczęto akcję zmiany nazw ulic, która do 1944 r. objęła łącznie 237 ciągi komunikacyjne oraz place ${ }^{13}$. Na Rynku Głównym (od 1941 r. Adolf Hitler Platz) oraz na licznych budynkach powiewały rzędy flag ze swastyką ${ }^{14}$. Wszystkie polskie sklepy w centrum musiały posiadać niemieckie napisy. Jakkolwiek tego rodzaju zniemczanie otoczenia stało się udziałem wielu okupowanych miast, to w stołecznym Krakowie do zabiegów tych przywiązywano szczególną wagę.

Gwałtowna germanizacja przestrzeni była zjawiskiem typowym dla całego okupowanego przez III Rzeszę terytorium Polski, jednak Kraków, jako stolicę z całą pewnością wyróżniały poważne inwestycje infrastrukturalne. Najbardziej intensywne prace prowadzono zwłaszcza w pierwszych latach okupacji (do rozpoczęcia wojny III Rzeszy z ZSRR). Już w czerwcu 1940 r. ogłoszono powstanie dzielnicy niemieckiej, która obejmowała całą zachodnią, bardziej nowoczesną część miasta. Jej granice nigdy nie zostały do końca określone, niemniej na jej terenie wybudowano największe w Generalnym Gubernatorstwie nowe osiedle mieszkaniowe, obejmujące około 100 bloków i zrealizowane zgodnie z zasadami programu Licht und Luft, a więc zapewniające mieszkańcom przestrzeń, tereny zielone i światło $^{15}$. Na tym nie koniec. W okresie okupacji podjęto prace na rzecz

9 „Krakauer Zeitung” 1940, nr 13, s. 1.

10 A. ChWALBA, op. cit., s. 66.

${ }^{11}$ D. SCHENK, op. cit., s. 98-101.

12 A. Chwalba, op. cit., s. 66.

13 A. CzOcher, op. cit., s. 28; M. KLUCZEWSKI, Bez zaciemnienia. Codzienność okupowanego Krakowa w materiatach Archiwum Państwowego w Krakowie, Kraków 2009, s. 38-40.

${ }^{14}$ K. LANCKOROŃSKa, Wspomnienia wojenne, Kraków 2005, s. 65.

15 A. ChWAlBA, op. cit., s. 70-72; M. KLUCZEWSKI, op. cit., s. 51-54. 
regulacji rzek Wisły oraz Wilgi, a także remontowano gmachy (np. gimnazjum Sobieskiego), a także Teatr Stary oraz gmach Sokoła ${ }^{16}$.

Najbardziej chyba znaną oraz spektakularną niemiecką inwestycją na terenie Krakowa wydaje się wybudowany w latach 1940-1942 Schloss Wartenberg - „zamek” w Przegorzałach, zlokalizowany w bezpośrednim sąsiedztwie willi Adolfa Szyszko-Bohusza i tworzący wraz z nią malowniczy kompleks zlokalizowany na wysokiej skale ${ }^{17}$. Ta zaprojektowana w „stylu III Rzeszy” rezydencja została podarowana przez Hansa Franka Heinrichowi Himmlerowi ${ }^{18}$. Intensywny ruch budowlany nie ominął też samego Wzgórza Wawelskiego. Na potrzeby biur przebudowany został budynek dawnych kuchni królewskich, a od strony ulicy Bernardyńskiej postawiono nową bramę wjazdową, której nadano kształt nawiązujący do architektury średniowiecza ${ }^{19}$. Mało który krakowianin zdaje też sobie sprawę, że okupacyjną genezę posiadają też arkady przy ulicach Grodzkiej oraz Krakowskiej ${ }^{20}$.

Należy mieć świadomość, że plany okupantów były jednak znacznie ambitniejsze i obejmowały nie tylko remonty, przebudowy oraz inwestycje mieszkaniowe. Już w 1940 r. rozpoczęto pracę nad zaprojektowaniem nowej, reprezentacyjnej „dzielnicy rządowej”, zlokalizowanej w położonej nad Wisłą dzielnicy Dębniki. Podobny kompleks monumentalnych gmachów powstać miał przez zabudowę krakowskich Błoń, przy czym projekt zakładał całkowitą niwelację kopców Kościuszki oraz Piłsudskiego jako symboli polskiej kultury i tożsamości narodowej ${ }^{21}$. Planowano również zupełnie zburzyć Kazimierz oraz przebudować krakowski ratusz ${ }^{22}$.

16 A. Czocher, op. cit., s. 24-26.

17 M. Fabiański, J. PurChla, Historia architektury Krakowa w zarysie, Kraków 2001, s. 319.

18 Pierwotnie budowę zameczku rozpoczął gubernator dystryktu krakowskiego Otto von Wächter. Po jego przeniesieniu do Lwowa inwestycję zakończył Hans Frank, po czym podarował tę rezydencję H. Himmlerowi, vide: M. RożEK, Przewodnik po zabytkach Krakowa, Kraków 2006, s. 499.

19 K. Kuczman, Wawel. Przewodnik, Kraków 1999, s. 24 i 28; vide: J. GwizdaŁówna, Wawel podczas okupacji niemieckiej 1939-1945. Przemiany architektury. Echa architektury nazistowskiej, „Rocznik Krakowski” 2011, t. 77, s. 113-141.

20 J. PurCHLA, Architektura III Rzeszy w Krakowie - dziedzictwo ktopotliwe, „Rocznik Biblioteki Kraków” 2019, R. 3, s. 39.

21 M. KluCZEWski, op. cit., s. 50; M. RożEK, op. cit., s. 506; K. WAKSMUndzki, Kopiec Józefa Pitsudskiego - kopiec niepodlegtości, „Rocznik Krakowski” 1986, t. 52, s. 127.

22 A. Chwalba, op. cit., s. 55. 
Niezależnie od tych planów oraz mimo wszystko ograniczonych inwestycji zdecydowanie najbardziej trwałym rezultatem działalności niemieckich urbanistów okazało się przyłączenie do Krakowa ościennych miejscowości. Dnia 28 maja 1941 r. zgodnie z decyzją Wydziału Głównego Spraw Wewnętrznych rozszerzono granice miasta o tereny 2 gmin oraz 28 gromad wiejskich, co spowodowało włącznie do stolicy Generalnego Gubernatorstwa obszaru o powierzchni $11885 \mathrm{~km}^{2}$, zamieszkałego przez ponad 72 tys. osób $^{23}$. W skład Krakowa weszły wówczas rozpoznawalne dzisiaj dzielnice, takie jak np. Biały i Czerwony Prądnik, Bronowice, Prokocim, Bieżanów, Piaski Wielkie, Kurdwanów ${ }^{24}$. Było to największe rozszerzenie granic w dziejach miasta i jak się okazało - stworzyło ono administracyjne podstawy do gwałtownego rozwoju urbanistycznego podwawelskiego ośrodka w okresie powojennym ${ }^{25}$.

Rozpatrując zagadnienie wpływu stołeczności Krakowa na życie poszczególnych grup ludności, nie sposób nie odnieść się do losów krakowskich Żydów. Już na wstępie musimy zaznaczyć, że sprawy tej w niniejszym artykule nie będziemy szerzej omawiać, gdyż stanowi ona osobny problem - niezwykle złożony i posiadający własną, bogatą literaturę ${ }^{26}$. Dość stwierdzić, że o istotnym wpływie faktu stołeczności miasta na losy tej społeczności możemy mówić właściwie tylko w jednym momencie, w pierwszych miesiącach okupacji. Podjęto wówczas decyzję, że ze względu na powstanie pod Wawelem dużego skupiska ludności niemieckiej konieczne jest wysiedlenie większości żydowskich mieszkańców Krakowa. Na posiedzeniu kierowników działów $12 \mathrm{kwietnia} 1940 \mathrm{r}$. Hans Frank argumentował: „Jeśli autorytet państwa narodowo-socjalistycznego ma być utrzymany, to jest rzeczą niemożliwą, aby reprezentanci tego państwa musieli przy wchodzeniu i wychodzeniu z domu spotykać się z Żydami i aby im groziło

23 Verordnungsblatt für das Generalgouvernement (Dziennik Rozporządzen dla Generalnego Gubernatorstwa), nr 51 (1941), s. 322-323; http://dlibra.umcs.lublin.pl/dlibra/publication?i$\mathrm{d}=12481 \& \mathrm{tab}=3$ (dostęp: 16 I 2021).

${ }^{24}$ Granice miasta, [w:] Encyklopedia Krakowa, red. A.H. STACHOwsKI, Kraków 2000, s. 259.

25 Vide: A. LitewKA, Rozszerzenie granic Krakowa 1941-1948, „Studia Historyczne” 1984, t. 27, s. 3, s. 475-489.

26 Vide: A. BiebersteIn, Zagtada Żydów w Krakowie, Kraków 1985; R. KotARBA, Niemiecki obóz w Ptaszowie 1942-1945, Kraków-Warszawa 2009; A. LÖw, M. RoTH, Krakowscy Żydzi pod okupacja niemieckq 1939-1945, Kraków 2014; K. ZiMMERER, Zamordowany świat. Losy Żydów w Krakowie 1939-1945, Kraków 2004. 
niebezpieczeństwo epidemii”27. W rezultacie rozpoczęto planowanie wielkiej akcji wysiedleńczej, która miała doprowadzić do pozostawienia w Krakowie jedynie 5-10 tys. Żydów - niezbędnych rzemieślników oraz profesjonalistów ${ }^{28}$.

Początkowo starano się przekonać Żydów do wyjazdu dobrowolnego. W ogromnej większości nie chcieli oni opuszczać swojego rodzinnego miasta, tym bardziej że w warunkach okupacyjnych znalezienie nowego miejsca do życia bynajmniej nie było łatwe ${ }^{29}$. W związku z brakiem zadowalających rezultatów akcji przesiedleńczej w maju 1940 r. Niemcy zarządzili przymusową deportację, realizowaną od 16 sierpnia 1940 r. ${ }^{30}$ Dla wielu rodzin oznaczało to konieczność rozpoczęcia dramatycznej walki o załatwienie możliwości pozostania w mieście $^{31}$. Decydowały o tym komisje złożone z przedstawicieli Judenratu oraz władz okupacyjnych. Osoby, które nie uzyskały stosownych dokumentów, kierowane były głównie do mniejszych, często nieznanych sobie miejscowości ${ }^{32}$. Ich pozostawiony w mieście majątek przejmowała niemiecka administracja. Ostatecznie z ok. 65 tys. krakowskich Żydów do 1 listopada 1940 r. wysiedlono ok. 32 tys. ${ }^{33}$ Kolejnych 20 tys. osób usunięto z miasta w listopadzie i grudniu, nierzadko w wyniku ulicznych łapanek ${ }^{34}$. Pozostali, w liczbie ok. 15-17 tys., zostali zmuszeni do przeniesienia się do getta, utworzonego w marcu 1941 r. na terenie dzielnicy Podgórze ${ }^{35}$. Ich dalszy, tragiczny los nie odbiegał w znaczący sposób od dramatu Żydów w innych miejscowościach Generalnego Gubernatorstwa ${ }^{36}$.

${ }_{27}$ K. ZIMMERER, Kronika zamordowanego świata. Żydzi w Krakowie w okresie okupacji niemieckiej, Kraków 2017, s. 72.

28 S. Piotrowski, Dziennik Hansa Franka, Warszawa 1956, s. 408; D. SCHENK, op. cit., s. 149.

29 A. Löw, M. RoTH, op. cit., s. 36.

30 Okupacja i ruch oporu w dzienniku Hansa Franka 1939-1945, t. 1: 1939-1942, oprac. L. Dobroszycki, J.B. Gras, M. Getter, L. Herzog, A. Janowski, M. Malinowski, S. Peonka, Warszawa 1972, s. 187.

${ }^{31}$ K. ZIMMERER, Kronika zamordowanego świata..., s. 127-128.

32 A. Löw, M. Roth, op. cit., s. 47; K. ZIMMERER, Kronika zamordowanego świata..., s. 107.

33 A. ChWALBA, op. cit., s. 107.

${ }^{34}$ A. Löw, M. RoTH, op. cit., s. 45.

35 C. Brzoza, Postowie, [w:] T. Pankiewicz, Apteka w getcie krakowskim, Kraków 1995, s. 259.

${ }^{36}$ Krakowskie getto zostało ostatecznie zlikwidowane w marcu 1943 r. Większość jego mieszkańców zginęła bezpośrednio podczas likwidacji getta albo w komorach gazowych obozu zagłady Bełżec (również w Auschwitz-Birkenau). Osoby „zdolne do pracy” w większości stały się więźniami obozu koncentracyjnego Płaszów lub jednego z jego podobozów, vide: C. BRzoZA, op. cit., s. 258263; J. SaChslehner, Kat z Listy Schindlera. Zbrodnie Amona Leopolda Götha, Kraków 2010, s. 86-91. 
Istotne jest również pytanie, w jaki sposób szczególny status Krakowa oddziaływał na życie polskich mieszkańców miasta. Przede wszystkim musimy pamiętać o tym, że miejscowa ludność poddawana była tym samym procesom, które zachodziły we wszystkich innych miejscowościach Generalnego Gubernatorstwa. Z całą pewnością istniały jednak elementy, które wyróżniały doświadczenie krakowian. Nie ulega wątpliwości, że dla niektórych mieszkańców miasta pojawiły się dodatkowe możliwości zarobkowania. Jakkolwiek polsko-niemieckie stosunki poddane zostały regulacjom dotyczącym segregacji rasowej, to faktyczne rozdzielenie tych dwóch społeczności nie było w żaden sposób możliwe. Niemcy na każdym kroku zmuszeni byli korzystać z usług Polaków. Zarabiać mogli lekarze, woźnice, kierowcy, kelnerzy, sprzątaczki, a nawet prostytutki. Chociaż formalnie Niemcy posiadali swoje własne sklepy, to jednak chętnie zaopatrywali się u polskich handlarzy (szczególnie pod koniec okupacji). Wynikało to z niepozbawionego racji przekonania, że Polacy mają łatwiejszy dostęp do produktów pochodzących z czarnego rynku ${ }^{37}$. Należy też pamiętać, że chociaż pośród urzędników państwowych dominowali Niemcy, to już w administracji miejskiej większość zatrudnionych przez cały czas trwania okupacji stanowili Polacy. W marcu 1944 r. we wszystkich krakowskich urzędach oraz instytucjach pracowało niemal 35 tys. osób tej narodowości ${ }^{38}$. Można było ich zresztą spotkać w większości zainstalowanych w stolicy Generalnego Gubernatorstwa instytucji, nawet tak zideologizowanych jak Niemiecki Instytut Pracy Wschodniej ${ }^{39}$. Niejednokrotnie przybysze z Rzeszy wynajmowali też u Polaków pokoje. Chociaż władze nakłaniały Reichsdeutschów do przeprowadzki do dzielnicy niemieckiej, ci jednak chętnie zamieszkiwali wśród Polaków, licząc na możliwość drobnego handlu oraz nienarażanie się na ewentualne bombardowania. Z kolei Polacy nie stronili od wynajmowania pokoi Niemcom, co, jak sądzono, może uchronić przed utratą mieszkania oraz wypracować kluczowe dla przetrwania kontakty ${ }^{40}$. Nie można wreszcie zapominać, że za niemieckimi

${ }^{37}$ A. ChWALBA, op. cit., s. 66. Interesujący opis życia gospodarczego, handlu, pracy i czarnego rynku w okresie okupacji, vide: K. WYKA, Gospodarka wytaczona, [w:] IDEM, Życie na niby. Szkice z lat 1939-1945, Warszawa 1957.

38 C. MadajCzyK, Polityka III Rzeszy w okupowanej Polsce, t. 2, Warszawa 1970, s. 125.

39 Pod koniec okupacji Polacy stanowili nawet $2 / 3$ pracowników. A. RYBICKA, Instytut Niemieckiej Pracy Wschodniej. Institut für Deutsche Ostarbeit 1939-1945, Warszawa 2002, s. 139-154.

40 Choć zdarzały się również sytuacje, że niemiecki lokator doprowadzał ostatecznie do usunięcia polskich właścicieli, po czym sam przejmował mieszkanie, vide: A. Czocher, op. cit., s. 149. 
wojskowymi oraz urzędnikami przyjeżdżali też przedsiębiorcy, żeby wymienić tylko najsłynniejszego z nich Oskara Schindlera. Otwierając w stolicy - w bezpośredniej bliskości władzy - zakłady przemysłowe, chętnie korzystali oni zarówno z polskiej, jak i żydowskiej siły roboczej ${ }^{41}$.

Intensywność tych polsko-niemieckich relacji nie powodowała bynajmniej, że życie miejscowej ludności było wygodne i dostatnie. Przez cały czas trwania okupacji podlegali oni rygorystycznemu systemowi reglamentacji żywności, nie wspominając już o jakże typowym dla Generalnego Gubernatorstwa wszechobecnym terrorze oraz represjach. Krakowianie cały czas żyli w cieniu eksterminacji swoich żydowskich sąsiadów, obozu koncentracyjnego Płaszów oraz nieodległego Auschwitz-Birkenau. Niemniej dodatkowe możliwości, które stwarzała stołeczność, czyniły okupację w Krakowie nieco łatwiejszą do przetrwania.

Musimy też zdać sobie sprawę, że funkcjonowanie pod Wawelem centralnego ośrodka Generalnego Gubernatorstwa w pewnej mierze przysparzało mieszkańcom problemów. Chodzi w szczególności o kwestię przejmowania przez Niemców nieruchomości. Dotyczyło to zwłaszcza obszarów, na których władze okupacyjne tworzyły dzielnicę niemiecką, ale nie tylko - również w innych częściach miasta "polowano” na eleganckie lokale mieszkalne w celu przekazania ich przybyszom z Rzeszy ${ }^{42}$. Polaków bezpardonowo przesiedlano np. z osiedla Oficerskiego, przenosząc ich po likwidacji getta do Podgórza ${ }^{43}$. W efekcie tych rabunków Kraków stał się miastem niezwykle ciasnym i zatłoczonym, gdzie mocno dawał się we znaki deficyt dostępnej powierzchni mieszkalnej. Sytuację pogarszało też przybywanie pod Wawel, jako do miejsca względnie spokojnego, tysięcy osób deportowanych przez Niemców z terenów przyłączonych do Rzeszy (np. z Wielkopolski), później zaś - wygnanych ze zniszczonej Warszawy ${ }^{44}$.

Analizując wpływ stołeczności na wojenne losy miasta, zwykło się również podnosić jeszcze jeden aspekt - w Krakowie bardzo trudno było prowadzić skuteczną działalność konspiracyjną. W mieście, w którym w stosunku do ogólnej liczby mieszkańców oraz niezbyt dużej powierzchni żyło tak wielu Niemców,

41 Vide: M. BeDnAReK, Deutsche Emailwarenfabrik Oskara Schindlera w Krakowie w latach 19391945, „Krzysztofory” 2004, nr 22, s. 127-143; D. SCHENK, op. cit., s. 156; A. Löw, M. RoTH, op. cit., s. 81.

42 K. LANCKOROŃSKA, op. cit., s. 84.

43 S. MrożeK, Baltazar. Autobiografia, Warszawa 2006, s. 84.

44 A. ChWALBA, op. cit., s. 352-361. 
niełatwo było o lokale, skrytki czy też jakiekolwiek tajne zebrania. W literaturze przedmiotu niejednokrotnie podkreśla się, że w rezultacie w porównaniu z Warszawą konspiracja w Krakowie rozwijała się w sposób mniej dynamiczny. Nie zmienia to jednak faktu, że Kraków był drugim po Warszawie ośrodkiem polskiego ruchu oporu ${ }^{45}$. Warto pamiętać, że to przede wszystkim polska konspiracja w Krakowie (Związek Walki Zbrojnej - Armia Krajowa) mozolnie tworzyła szlaki kurierskie prowadzące głównie na Węgry ${ }^{46}$.

Stołeczność Krakowa wiązała się również z innym, nader widocznym w czasie drugiej wojny światowej zagadnieniem - miasto stało się centralnym punktem działalności propagandowej władz Generalnego Gubernatorstwa. Odpowiadał za nią w pierwszej kolejności Główny Wydziałds. Oświecenia Narodowego i Propagandy, który należał do struktur Urzędu Generalnego Gubernatora. Siedziba tej instytucji znajdowała się w Krakowie przy Rynku Kleparskim 4. Jej pracami kierował początkowo Max du Prel, a od lipca 1940 r. Wilhelm Ohlenbusch ${ }^{47}$. Urząd ten dzielił się na poszczególne wydziały do spraw prasy, propagandy, kultury, filmu, radia, wydawnictw, piśmiennictwa i kwestii narodowościowych. Wydziały do spraw propagandy funkcjonowały ponadto w każdym z dystryktów Generalnego Gubernatorstwa. Zachowana w archiwach korespondencja tych instytucji świadczy również o tym, że jakkolwiek podlegały one gubernatorowi Hansowi Frankowi, to pozostawały w kontakcie z Ministerstwem Propagandy w Berlinie ${ }^{48}$. Opisując tę strukturę, musimy jednak pamiętać, że niejako z definicji nie była ona klarowna. Podobnie jak pod każdym innym względem, tak również jeśli chodzi o administrację, naziści powielali w Generalnym Gubernatorstwie schematy znane im z Rzeszy. Tamtejszy system określa się jako polikratyczny - charakteryzowała go wielość struktur oraz instytucji, których kompetencje się nakładały ${ }^{49}$. Powodowało to częste spory oraz wysoki poziom spersonalizowania, co oznacza, że kluczową rolę w funkcjonowaniu państwa odgrywały nie tyle procedury oraz jasno sprecyzowane kompetencje, co osobista pozycja oraz wypływy poszczególnych funkcjonariuszy reżimu.

45 J. Chrobaczyński, Kraków - „stolica”..., s. 241; A. PANKowicz, ZWZ-AK w życiu podziemnego Krakowa, [w:] Kraków w czasie II wojny światowej, red. J.M. MAŁECKI, Kraków 1992, s. 47-59.

${ }^{46}$ A. ChWALBA, op. cit., s. 278.

47 D. SCHENK, op. cit., s. 95.

48 Bundesarchiv Berlin (dalej: BA), Reichsministerium für Propaganda - Ministerstwo Propagandy Rzeszy (dalej: R-MP), R 55, mikrofilm 1206, k. 8, 10, 17, 18, 23, 24.

49 M. Winstone, Generalne Gubernatorstwo. Mroczne serce Europy, Poznań 2015, s. 77. 
W pierwszych latach wojny celem nazistowskiej propagandy pozostawało przede wszystkim utrzymanie społeczeństwa w posłuszeństwie wobec okupanta ${ }^{50}$. Działania te z jednej strony miały wyrobić przekonanie o niemieckiej sile militarnej, nieuchronnym zwycięstwie III Rzeszy w toczącej się wojnie oraz absolutnej wyższości kulturalnej „żywiołu germańskiego” nad „żywiołem polskim”. Konsekwencją miało być poczucie bezsensowności wszelkiego oporu. Z drugiej strony starano się też pokazać, że jeśli ogół Polaków będzie akceptować władze Generalnego Gubernatorstwa, a nade wszystko spokojnie pracować, to możliwa stanie się pewna stabilizacja, a nawet korzystanie z niemieckich zdobyczy cywilizacyjnych ${ }^{51}$.

Od samego początku niemieckiego panowania na ziemiach polskich intensywnie eksploatowanym tematem był również antysemityzm. Za wyjątkowo perfidny przykład realizowania w Krakowie tego typu zabiegów uznać można choćby otwartą we wrześniu 1943 r. w Sukiennicach wystawę ukazującą zgubny wpływ Żydów na zdrowie oraz higienę mieszkańców miasta ${ }^{52}$.

Skoncentrowana wokół tych wątków propaganda wykorzystywała konkretne środki przekazu. Podstawowe medium stanowiła prasa. Wynikało to m.in. z przyczyn ideologicznych, np. z faktu, że w opinii nazistów Polacy, jako ludność podbita i upośledzona pod względem kulturalnym, nie byli godni posiadania nadającej w narodowym języku rozgłośni radiowej. Już na samym początku okupacji, jesienią 1939 r., pozamykano ostatnie przedwojenne gazety, po czym szybko uruchomiano system prasy „gadzinowej”. I tak 27 października 1939 r. rozpoczęto wydawanie „Gońca Krakowskiego”, którego nakład osiągnął 60 tys. egzemplarzy ${ }^{53}$. Obok prasy polskojęzycznej ukazywała się także prasa w języku niemieckim. Jej najważniejszym tytułem była „Krakauer Zeitung”, przy czym z całą pewnością należy traktować tę gazetę jako element propagandy skierowanej do mieszkających w Generalnym Gubernatorstwie Niemców oraz Volksdeutschów ${ }^{54}$. Pomimo ograniczonej grupy odbiorów nakład gazety w $1941 \mathrm{r}$. osiągnął 100 tys. egzemplarzy, a w kolejnych latach nawet 140 tys.55

${ }^{50}$ D. SCHENK, op. cit., s. 96.

51 A. ChWALBA, op. cit., s. 227.

52 D. SCHENK, op. cit., s. 158-161; vide: Narodowe Archiwum Cyfrowe (dalej: NAC), Plakat $\mathrm{z}$ antysemickiej wystawy „Żydowska zaraza światowa” wystawianej w Sukiennicach, sygn. 2-11626.

53 A. ChWAlBA, op. cit., s. 226.

${ }^{4}$ Szerzej na ten temat, vide: P. KOŁTUNOWSKI, „Krakauer Zeitung” $w$ systemie propagandy hitlerowskiej, „Kwartalnik Historii Prasy Polskiej” 1986, R. 25, nr 2, s. 41-63.

55 D. SCHENK, op. cit., s. 95. 
Rzecz jasna prasa niemieckojęzyczna oraz gadzinowa ukazywała się nie tylko w Krakowie, ale też w innych miastach Generalnego Gubernatorstwa. Oblicza się, że w języku polskim wydawano dziewięć gazet codziennych, cztery tygodniki i dwadzieścia czasopism fachowych ${ }^{56}$. Nie zmienia to jednak faktu, że z racji swojej stołeczności centrum tej akacji propagandowej stanowił Kraków. Sytuacja ta pogłębiła się jeszcze pod koniec wojny - w roku 1943, a zwłaszcza 1944, kiedy Niemcy w obliczu postępów Armii Czerwonej zaczęli podejmować wysiłki na rzecz zjednania sobie Polaków. Szczytowy moment tych działań przypada na lato oraz jesień 1944 r. ${ }^{57}$ Warto pamiętać, że w tym czasie cała wschodnia część Generalnego Gubernatorstwa (na wschód od Wisły) zajęta była już przez Armię Czerwoną, natomiast w Warszawie trwało powstanie, stąd też ta bezprecedensowa akcja propagandowa musiała być prowadzona przede wszystkim pod Wawelem.

Aby w pełni zrozumieć podejmowane przez władze okupacyjne działania, musimy je zobaczyć w kontekście tzw. nowego kursu wobec Polaków, jaki w 1943 r. zaproponował gubernator Hans Frank. Otóż 15 lutego wystosował on do najwyższych władz III Rzeszy okólnik, w którym zasugerował konieczność poczynienia doraźnych ustępstw wobec Polaków ${ }^{58}$. Propozycje generalnego gubernatora napotkały zdecydowany opór najbardziej wpływowych funkcjonariuszy kancelarii Rzeszy, w tym Martina Bormanna oraz Heinricha Himmlera. Na wprowadzenie nowego kursu nie zgodził się również sam Hitler, który wyraźnie określił swoje stanowisko w rozmowie z H. Frankiem 9 maja 1943 r. Generalny gubernator nie dawał jednak za wygraną i jeszcze przynajmniej raz, 19 czerwca 1943 r. przedstawił swoje racje w kolejnym obszernym, skierowanym do Hitlera raporcie ${ }^{59}$. Nic jednak nie wskazuje na to, aby stanowisko przywódcy III Rzeszy uległo zmianie.

Choć koncepcja elastycznego kursu - przynajmniej na poziomie oficjalnym - upadła, to w działaniach podejmowanych w Krakowie w latach 1943-1944 wyraźnie widać elementy tego podejścia ${ }^{60}$. W marcu 1944 r. uruchomiono teatr

56 Ibidem.

57 K. Grünberg, B. OTręBA, Hans Frank na Wawelu, Włocławek 2001, s. 215-241.

58 J. CHROBACZYŃSKI, Wojna a spoteczeństwo..., s. 183.

59 BA, R 52 II 12, Berichte des Generalgouverneurs an der Fubrer und Reichkanzler an der Chef der Sicherheits polizei und des SD, Kaltenrunner uber die deutsche Polenspolitik im Generalgouvernement, k. $1-21$.

60 J. ChrobaczyŃski, Wojna a spoteczeństwo..., s. 184. 
powszechny ${ }^{61}$. Władze podjęły też pewne kroki w celu ograniczonego rozwoju szkolnictwa, przede wszystkim powszechnego oraz zawodowego. Przykładem mogło być otwarcie w Krakowie nowej polskiej szkoły powszechnej, gdzie obok portretów H. Franka oraz Józefa Piłsudskiego umieszczono biało-czerwoną flagę ${ }^{62}$. Takich gestów generalny gubernator czynił w tym czasie więcej. Zezwolono na sprzedaż Polakom biletów do krakowskiej Filharmonii ${ }^{63}$. W numerze z 17 listopada 1944 r. „Goniec Krakowski” donosił o serdecznym spotkaniu dożynkowym H. Franka z delegacją polskich rolników ${ }^{64}$. Zasadniczo w 1944 r. działania wizerunkowe oraz propagandowe władz okupacyjnych, mające na celu zjednanie sobie Polaków, przybrały postać w miarę zorganizowanej akcji o kryptonimie „Berta"65. W jej ramach to głównie Kraków zasypywany był ulotkami oraz plakatami o charakterze antybolszewickim. Wyjątkowo śmiałym i wartym odnotowania zabiegiem było odwołanie się nazistowskich propagandzistów do postaci J. Piłsudskiego. W kolportowanych na terenie Krakowa materiałach powoływali się oni na autorytet Marszałka, a także na pamięć o bitwie warszawskiej z 1920 r. ${ }^{66} \mathrm{~W}$ sposób bezpardonowy Niemcy eksploatowali także sprawę zbrodni katyńskiej ${ }^{67}$.

Niezwykle ciekawą kwestią wydaje się sprawa reakcji polskiej ludności Krakowa na niemieckie działania propagandowe w 1944 r. Najważniejsze pozostaje rzecz jasna pytanie o ewentualną skuteczność tej propagandy. Zarówno władze Generalnego Gubernatorstwa, jak i prasa gadzinowa próbowały za wszelką cenę nagłośnić wszelkie przypadki kolaboracji Polaków. W czasie posiedzenia rządu Generalnego Gubernatorstwa 7 lipca 1944 r. H. Frank donosił swoim współpracownikom o powstaniu bliżej niesprecyzowanej polskiejligi antybolszewickiej i twierdził,że Polacy poparliNiemców, ponieważzorientowalisię, że nie mająinnego wyjścia ${ }^{68}$. Wszystko wskazuje na to, że H. Frank mówił to na wyrost, skoro 1 sierpnia 1944 r. w piśmie sformułowanym na sześć godzin przed wybuchem powstania warszawskiego (sic!)

61 Ibidem.

62 Ibidem, s. 183.

63 K. Grünberg, B. OtręBA, op. cit., s. 219.

64 „Goniec Krakowski” 1944, nr 270, s. 3.

65 K. Grünberg, B. OTręBA, op. cit., s. 230.

66 ANK, Akta Miasta Krakowa, Urząd Kultury i Propagandy (dalej: UKiP), 29/33/0/5.3/SMKr, mikrofilm 8190, k. 283.

67 Ibidem, k. 428-442.

68 BA, Kanzlei des Generalgouverneurs - Kancelaria Generalnego Gubernatorstwa (dalej: KGG), R 52-II, mikrofilm 246, k. 9. 
szef krakowskiego wydziału propagandy Wilhelm Ohlenbusch zarysował plan powstania tego typu proniemieckiej organizacji politycznej ${ }^{69}$. Być może rzeczywiście przez krótki czas ona istniała i funkcjonowała w Krakowie pod patronatem władz okupacyjnych. W sierpniu 1944 r., a więc w czasie, gdy w Warszawie trwało powstanie, pod Wawelem struktura określająca się jako Niezależny Polski Komitet Narodowy do Zwalczania Komunizmu i Masonerii kilkukrotnie kierowała do H. Franka odręczne pisma potwierdzające poparcie narodu polskiego dla niemieckich władz okupacyjnych ${ }^{70}$. Biorąc jednak pod uwagę, że sprawa ta szybko zniknęła z dokumentacji centralnych władz Generalnego Gubernatorstwa, a także brak jakichkolwiek innych wzmianek o tej organizacji, można przyjąć, że była to struktura efemeryczna, jeśli nie zupełnie fikcyjna.

Z całą pewnością skutek (acz niewielki) odniosły w Krakowie apele o wstępowanie do służby pomocniczej niemieckich sił zbrojnych ${ }^{71}$. Przy ul. Lubomirskiego 19 założono nawet biuro werbunkowe i zaczęto formować kompanię piechoty w sile 170 ludzi. Ostatecznie udało się zwerbować 471 osób ${ }^{72}$. W „Gońcu Krakowskim” pojawiła się nawet informacja o tym, jakoby ulicami Krakowa przemaszerował oddział liczący 30 mężczyzn i 15 kobiet ubranych w mundury niemieckie z biało-czerwonymi opaskami ${ }^{73}$. W numerze z 17 listopada 1944 r. gazeta ta donosiła, że setki tysięcy Polaków entuzjastycznie uczestniczy w budowaniu umocnień, aby wspomóc niemieckie siły zbrojne w odparciu bolszewizmu ${ }^{74}$. Faktycznie wszystko wskazuje na to, że w Krakowie frekwencja przy tych pracach była dość duża ${ }^{75}$. Skala zaangażowania mieszkańców miasta w budowę umocnień zaskoczyła nawet podziemie ${ }^{76}$. Mimo wszystko nie jesteśmy w stanie do końca stwierdzić, ile osób stawiło się na wezwanie władz okupacyjnych. Można też przypuszczać, że ich główną motywacją było nic innego jak tylko chęć spokojnego przetrwania końca okupacji. Zasadniczo reakcje ludności Krakowa

${ }^{69}$ BA, R-MP, R 55, mikrofilm 1206, k. 5-6.

${ }^{70}$ Pisma te zostały podpisane przez trudne do zidentyfikowania osoby podawane tylko z nazwiska: Rudnowski, Strażyński, Kowerski, BA, R 52 II, 11, Proteste und Eingaben aus den polischen Bevolkrung, k. 1, 5 .

${ }^{71}$ Przykłady plakatów nawołujących do wstępowania do służby pomocniczej, ANK, UKiP, mikrofilm 8190, k. 479.

\footnotetext{
72 A. Chwalba, op. cit., 220.

${ }^{73}$ Ibidem.

74 „Goniec Krakowski” 1944, nr 270, s. 1.

75 K. Grünberg, B. OTRĘBA, op. cit., s. 240.

76 A. Chwalba, op. cit., s. 223.
} 
na niemiecką propagandę wydają się nader skromne. W archiwum kancelarii Generalnego Gubernatorstwa zachowały się wyłącznie pojedyncze przypadki wiernopoddańczych pism kierowanych przez Polaków do H. Franka (przy czym niektóre z nich przybierają postać donosów) ${ }^{77}$.

Podsumowując powyższe rozważania na temat stołeczności Krakowa w okresie niemieckiej okupacji, warto raz jeszcze podkreślić odmienność losów tego miasta od jakiegokolwiek innego polskiego regionu bądź też ośrodka. Na ziemiach przyłączonych do III Rzeszy prowadzono przede wszystkim politykę intensywnej germanizacji. Z kolei na pozostałych (poza Krakowem) obszarach Generalnego Gubernatorstwa chodziło tylko o kontrolę nad podbitą ludnością. Tymczasem pod Wawelem doszło do wieloaspektowych procesów, które wymykają się uproszczeniom i łatwym ocenom. Z jednej strony nastąpił masowy napływ ludności niemieckiej, co powodowało faktyczne zniemczanie miasta - nie tylko na skutek odgórnych zarządzeń, ale też na poziomie społeczeństwa oraz jego codziennego funkcjonowania. $Z$ drugiej zaś strony cały czas większość mieszkańców podwawelskiego ośrodka stanowiła ludność polska, która funkcjonowała (i niejednokrotnie cierpiała) w reżimie okupacyjnym, ale jednocześnie czerpała ograniczone korzyści z napędzanej przez stołeczność miasta koniunktury. Wreszcie nie sposób nie zauważyć, że Kraków stał się jedyną w Generalnym Gubernatorstwie przestrzenią tak intensywnie poddawaną zabiegom ideologicznym oraz propagandowym. Warto w tym kontekście przytoczyć sformułowanie Czesława Madajczyka, który określił okupacyjny Kraków jako „prototyp nazistowskiej, kolonialnej okupacji”78. Z naciskiem na „kolonialnej”. Pod Wawelem doszło bowiem do próby realizacji swoistego eksperymentu, wdrażanego na różnych poziomach: społecznym, ideologicznym oraz propagandowym. Kraków miał zostać nie tylko przez okupantów ujarzmiony, ale był też przestrzenią przez Niemców zasiedlaną, kolonizowaną oraz zawłaszczaną (również w sensie symbolicznym). Los miasta pośrednio zatem ukazuje, jak mogłaby wyglądać nasza część Europy, gdyby wynik wojny okazał się dla III Rzeszy korzystny.

\footnotetext{
77 BA, R 52 II, 11, Proteste und Eingaben aus den polischen Bevolkrung, k. 15, 15, 21, 22, 26, 30.

78 Cit.per: J. ChrobaCZYŃski, Kraków - „stolica”..., s. 239.
} 


\section{BIBLIOGRAFIA}

\section{Źródła archiwalne}

Archiwum Narodowe w Krakowie

Akta Miasta Krakowa, Propaganda und Kulturamt (Urząd Kultury i Propagandy), 29/33/0/5.3/SMKr.

\section{Bundesarchiv Berlin}

Kanzlei des Generalgouverneurs (Kancelaria Generalnego Gubernatorstwa), R 52-II i Reichsministerium für Propaganda (Ministerstwo Propagandy Rzeszy), R 55.

\section{Źródła drukowane}

Lanckorońska K., Wspomnienia wojenne, Kraków 2005.

Mrożek S., Baltazar. Autobiografia, Warszawa 2006.

Okupacja iruch oporu w dzienniku Hansa Franka 1939-1945, t. 1: 1939-1942, oprac. L. Dobroszycki, J.B. Gras, M. Getter, L. Herzog, A. Janowski, M. Malinowski, S. Płonka, Warszawa 1972.

Pankiewicz T., Apteka w getcie krakowskim, Kraków 1995.

Piotrowski S., Dziennik Hansa Franka, Warszawa 1956.

\section{Prasa}

„Goniec Krakowski” 1944.

„Krakauer Zeitung” 1940.

\section{Opracowania}

Bednarek M., Deutsche Emailwarenfabrik Oskara Schindlera w Krakowie w latach 19391945, „Krzysztofory” 2004, nr 22, s. 127-143.

Chrobaczyński J., Kraków - „stolica” Generalgouvernement (1939-1945), [w:] Kraków. Studia z dziejów miasta. W 750 rocznicę lokacji, red. J. Rajman, Kraków 2007, s. 237-247.

Chrobaczyński J., Nauczyciele w okupowanym Krakowie 1939-1945, Kraków 1989. 
Chrobaczyński J., Wojna a spoteczeństwo. Ze studiów nad spotecznościq okupowanego Krakowa 1939-1945, Kraków 1989.

Chwalba A., Okupacyjny Kraków w latach 1939-1945, Kraków 2002.

Czocher A., W okupowanym Krakowie. Codzienność polskich mieszkańców miasta 19391945, Gdańsk 2011.

Encyklopedia Krakowa, red. A.H. Stachowski, Kraków 2000.

Fabiański M., Purchla J., Historia architektury Krakowa w zarysie, Kraków 2001.

Grünberg K., Otręba B., Hans Frank na Wawelu, Włocławek 2001.

Gwizdałówna J., Wawel podczas okupacji niemieckiej 1939-1945. Przemiany architektury. Echa architektury nazistowskiej, „Rocznik Krakowski” 2011, t. 77, s. 113-141.

Kluczewski P., Bez zaciemnienia. Codzienność okupowanego Krakowa w materiatach Archiwum Państwowego w Krakowie, Kraków 2009.

Kołtunowski P., „Krakauer Zeitung” w systemie propagandy hitlerowskiej, „Kwartalnik Historii Prasy Polskiej” 1986, R. 25, nr 2, s. 41-63.

Litewka A., Rozszerzenie granic Krakowa 1941-1948, „Studia Historyczne” 1984, t. 27, s. 3, s. 475-489.

Madajczyk C., Polityka III Rzeszy w okupowanej Polsce, t. 2, Warszawa 1970.

Pankowicz A., $Z W Z-A K w \dot{z y c i u ~ p o d z i e m n e g o ~ K r a k o w a, ~[w:] ~ K r a k o ́ w ~ w ~ c z a s i e ~ I I ~ w o j n y ~}$ światowej, red. J.M. Małecki, Kraków 1992, s. 47-59.

Purchla J., Architektura III Rzeszy w Krakowie - dziedzictwo ktopotliwe, „Rocznik Biblioteki Kraków” 2019, R. 3, s. 15-54.

Rożek M., Przewodnik po zabytkach Krakowa, Kraków 2006.

Rybicka A., Instytut Niemieckiej Pracy Wschodniej. Institut für Deutsche Ostarbeit 19391945, Warszawa 2002.

Sachslehner J., Kat z Listy Schindlera. Zbrodnie Amona Leopolda Götha, Kraków 2010.

Schenk D., Krakauer Burg. Wawel jako ośrodek wtadzy Hansa Franka w latach 1939-1945, Kraków 2013.

Waksmundzki K., Kopiec Józefa Pitsudskiego - kopiec niepodlegtości, „Rocznik Krakowski” 1986, t. 52, s. 123-137.

Winstone M., Generalne Gubernatorstwo. Mroczne serce Europy, Poznań 2015.

Zimmerer K., Kronika zamordowanego świata. Żydzi w Krakowie w okresie okupacji niemieckiej, Kraków 2017.

Zimmerer K., Zamordowany świat. Losy Żydów w Krakowie 1939-1945, Kraków 2004.

\section{Netografia}

Verordnungsblatt für das Generalgouvernement (Dziennik Rozporządzeń dla Generalnego Gubernatorstwa), nr 51 (1941), http://dlibra.umcs.lublin.pl/dlibra/publication?i$\mathrm{d}=12481 \& \mathrm{tab}=3$ (dostęp: 16 I 2021). 


\title{
Mateusz Drozdowski
}

\section{KRAKOW AS THE CAPITAL OF THE GENERAL GOVERNMENT CONSEQUENCES OF HOSTING THE NAZI-GERMAN AUTHORITIES FOR A LIFE OF THE CITY}

\begin{abstract}
Summary. Aim of the article is to analyze a specific situation of Krakow during the Nazi-German occupation, when the city played a role of a capital of the General Government. The city functioned under a typical occupation regime, however, at the same time it was a seat of the authorities. As a result thousands of German functionaries and their families settled in Krakow. It had significant impact on many aspects of functioning of Krakow, ranging from social and housing issues, through architecture, economy, methods of extermination of the Jewish population and finally organization of the Polish underground. A separate issue discussed in the article are the Nazi propaganda campaigns conducted mainly in Krakow. Due to limitations, all these issues are presented in a general way, nevertheless giving a picture of specificity of Krakow's war experience. Author indicates that the fate of the city is not typical for the Polish lands occupied by the Third Reich. Contradictory to the other places, Krakow was not only a city that was conquered and controlled, but we can see it as a beginning of a new, colonial, Nazi order in the Eastern Europe.
\end{abstract}

Keywords: Krakow, World War II, General Government, Nazi-German occupation, Hans Frank 